\title{
The Impact of sustainable tourism dimensions on the achievement of competitive advantages: Evidence from Iraqi tourism and Hospitality setting-Nineveh province
}

\author{
Hameed Al-Debi ${ }^{1}$, Saad ibraheem ${ }^{2}$, Hassan Ali Al. Mussawi ${ }^{3}$ \\ aldebihameed@gmail.com¹, saadih@ntu.edu.iq ${ }^{2}$, moosahassan@ hotmail.com $^{3}$ \\ Alzytoonah University, Jordan ${ }^{1}$, North Technology University ${ }^{2}$, Ministry of Transportation-Iraq ${ }^{3}$
}

\begin{abstract}
The present study was intended to determine the impact of sustainable tourism dimensions (STD) represented by effective sustainable management, social and economic benefits to the local communities, maximize benefits to cultural heritage, and preserving and protecting the green tourism environment, on competitive advantages in tourism and hospitality industry, particularly in Nineveh province in Iraq. The target population of our study is employees of hotels, travel agencies, restaurants, education tourism institutions in the Nineveh province. A convenience sample was selected from this population. Two hundred and six (206) valid questionnaires were retrieved from respondents. The findings of the study have indicated the existence of significant positive correlations between three dimensions of sustainable tourism (effective sustainable management of tourism companies, social and economic benefits to local communities, advantages arising from cultural heritage) on competitive advantages. However, results have shown the fourth dimension, green tourism environment have a negative effect on competitive advantages from community's perspectives.
\end{abstract}

Keywords: Sustainable Tourism, Competitive Advantages, Tourism Industry, Iraq.

\section{Introduction}

According to (UNWTO) (1: UNWTO (2019), edition Madrid, Spain), International Tourism Highlights, (2019 Edition) illustrated the important of the economy growing based on emerging technologies, new businesses that makes 5\% grew in 2018; this also indicated in Europe 51\%, Asia and Pacific 25\%, Americas 15\%, Africa 5\% and Middle East 4\%. At the same time, export earrings generated by tourism have grown to USD 1.7 trillion. (Europe 39\%, Asia and Pacific 30\%, Americas 23\%, Middle East 5\% and Africa 3\%). In short, tourism is helping to build better lives for millions of individuals and transforming whole communities comes more responsibility in ensuring effective destination management that minimizes any adverse effect of tourism in a sustainable manner for the benefit of all is more critical than ever. We need to grow more in value rather than just in volume especially in the region of the Middle East (Arab countries). digitalization, innovation, greater accessibility and societal changes are expected to continue shaping the tourism industry.

(UNWTO), defines sustainable tourism as "tourism that takes full account of impacts, addressing the needs of visitors, the industry, the environment and host communities". Tourism is an activity that can have a really big impact on sustainable development that shared between companies, tourist destinations and national, regional and local authorities in order to cover a wide tourist group of challenges and at the same time to remain competitive (Tanja et. al, 2013:220). In other hands, in gaining economic growth, enhancing life quality and maintaining environmental quality, including 
the community support for life span of the industry and its development (Tayllor, 1995, Eagles, Mc cool, and Haynes, 2002, sebele, 2010).

The global sustainable tourism criteria (2: Global sustainable tourism council (2017)) are an effort to come to a common understanding of sustainable tourism and are the minimum that any tourism business should aspire to reach. They are organized around four main themes: they are effective sustainability planning: maximizing social and economic benefits to the local community, enhancing cultural heritage: and reducing negative impacts to the environment. Although the criteria are initially intended for use by the accommodation and tour operation sectors, they have applicability to the entire tourism industry.

This study is based on the recommendations of the global sustainable tourism council (GSTC), when had been announced (2017) the "international year of sustainable tourism for development". Madrid, Spain. Hence the main objective of our study is to examine the impact of sustainable tourism dimension on competitive advantages from Nineveh community's perspectives, north of Iraq.

\section{Overview of Nineveh Governorate Tourism and Tourism sector}

With around $438 \mathrm{Km}^{2}$ occupied by 39 million population represent republic of Iraq that shared the border with Iran, Turkey, Kuwait, Saudi Arabia, Jordan and Syria. It has $58 \mathrm{Km}$ coastline at the south and with 18 provinces, three of them are with Kurdish Regional Government (KRG), an autonomous regional government recognized under the Iraqi constitution.

One of the north province is Nineveh that contains the Assyrian city from $25^{\text {th }}$ century BC to the $7^{\text {Th }}$ century. AD. It has an area of $37,323 \mathrm{Km}^{2}(14,410 \mathrm{sq}$. mi) and an estimated population of 2,453.000 people in 2003. It is the chief city and provincial capital in Mosul. The province of Nineveh has various tourism elements of archaeological, natural and religious, and we can summarize as follows ;( Clark, Heather (2014) Muslim Militants blow up tombs of biblical Jonah, Daniel in Iraq, http://christiannews,Dana,L.P.(2000) :512.

\subsection{The components of religious tourism (Islamic Christian)}

Islamic sites of Mosul, are of varied ages, the oldest being the Umayyad Mosque from 640 AD. And the modern being the Mosul grand mosque, and many more, were destroyed by (ISIS, or Daesh) in 2014, after their takeover of the city. In addition to many historical places mentioned by Clark, Heather (2014); Muslim Militants blow up tombs of biblical Jonah, Daniel in Iraq, http://christiannews. mosques of nur al-din, the mosque of the prophet Jonah, green mosque, and mosque of Jeris (Saint George), mosque and tomb of the prophet sheth etc. This also includes the old Christian churches and monasteries in Nineveh. Laterly most of the main attractive historical places and building are entirely destroyed during the 4 years of (ISIS) control (2014-2018), through Lioyed, Anthony (2017). Inside the Assyrian place revealed in the fight for Mosul, see http://www.thetimes.co.uk/edition; includes Historical churches and monasteries; church of Shamoun Al-safa, the oldest church in Mosul; Church of Mara Tom, Mare petion church; Ancient tahira church; St. George's monastery, Mar Matti monastery etc.

\subsection{The components of archaeological tourism}

There are several archaeological and historical areas in the province of Nineveh dating back to the distant past (C.2025BC-C. 1754 BC). Assur was a capital city and oldest remains of the Ishtar 
temple. The other cities, Nineveh was an ancient Assyrian city of upper Mesopotamia that was stated during the reign of shamshi- A dad (CL, 754 BC-C. 1721Bc). Al-Hadar city was the Arabian capital that is one of the old cities in northern Iraq, which is a well-known archaeological area that attracts a large number of local and Regional tourists annually. Jukowsky, Institute for archeology and the ancient world, (2011).

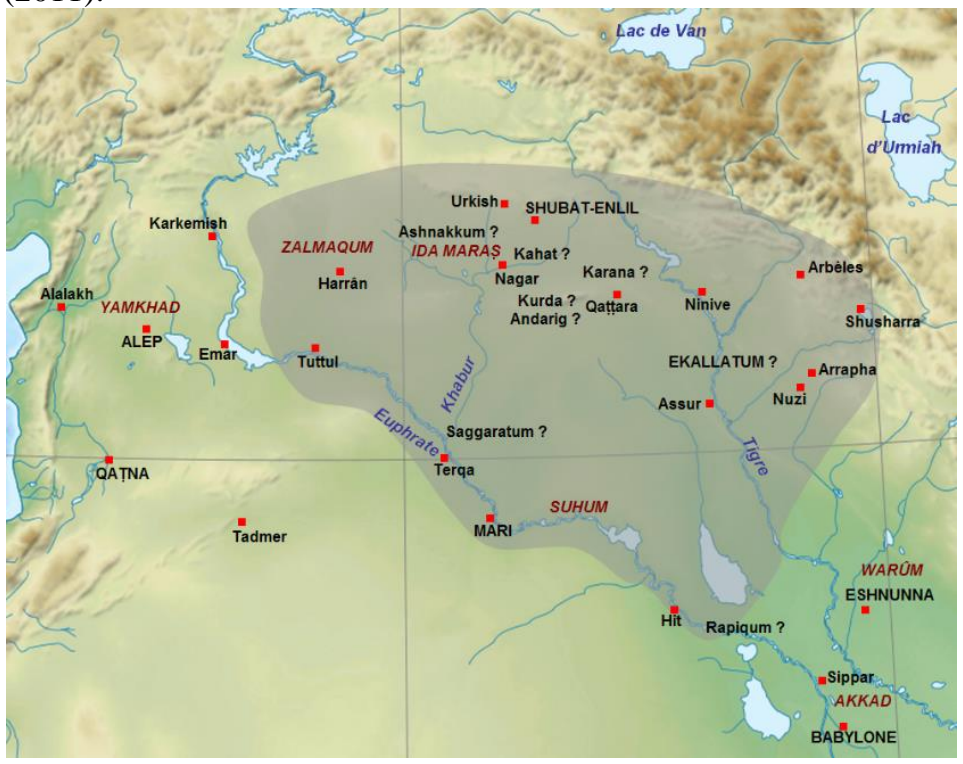

Figure (1), The old Assyrian period, K.R. Veenhof (2008) Mesopotamia: Vanden hoeck and Ruprechl: 24.

Mosul is characterized by Umm-Alrubiean (two spring seasons) because its atmosphere (forest and rivers) is very nice and moderate temperatures and therefore has been built a group of hotels, villages, tourist complexes and private restaurants as follows: (Commission of tourism, Nineveh 2017); (66) Hotels with a capacity of (3467) beds/night; (101) restaurants in many categories. Based on what has been presented above for tourist attraction available by the province of Nineveh one can say agreed well with (Tanja et.al, 2012) that defines the interests into the quality of the environment that depends on the cultural heritage such as the one found in Nineveh at the north of Iraq.

\section{Problem statement}

The problem of the study was formulated after caring out a pilot study of some, tourism, hotels, and educational companies and posing especial questions related to the outcomes of sustainable development of tourism sector in Nineveh governorate. In addition to relying on some previous studies in many regions in Europe \& Asia, and special reports issued by world tourism organization (UN.W.T.O.). The main question of the study problem: Is there an impact of the dimensions of sustainable tourism development on achieving competitive advantage in the Iraqi tourism industry to Nineveh government. A number of sub-questions emerge from this main question, reflect the impact on tourism Industry-Nineveh province such as, 
1. sustainable management of tourism companies (SMT).

2. benefits to local communities (BLC).

3. benefits arising from cultural heritage $(\mathrm{BCH})$.

4. preserving and protecting the green environment (GE).

\section{The purpose of study and objectives}

This study is an attempt to illustrate the mechanism by which competitive advantage in the tourism sector in Nineveh region, is achieved through the influence of different sustainable tourism dimensions. Accordingly, the main purpose of our study is to achieve an in-depth understanding of the synergic correlation between sustainable tourism practices and its effect on creating and motivating tourism marketing environment for hotels, restaurants, travel agents and educational institutions in Nineveh, which is expected to support the total performance of this vital important sector in the north of Iraq.

Therefore, the most important objectives of this study can be summarized as:

- To illustrate the sustainable tourism development practices conducted by decision-makers.

- Determining employers and decision-makers" degree of awareness to the importance of sustainable tourism sector in Nineveh.

- $\quad$ To gain more knowledge between Sustainable tourism and competitive advantages.

\section{Previous studies}

1- Sieglinde K da Cunha and J. Carlos da Cunha (2005): they measured the impact of tourism on local development. They detailed plan of guidelines and polices to improve competitiveness, cooperation and sustainability for private companies and institutions.

2- Tanja A., Cane K., Zlatko J., and Elizabeta M. (2012), this study confirmed there is quite good opportunities to preserve tourism development from its competitiveness.

3- João Romāo, G. Guerreiro and Paulo Rodringues (20017): in this study an analysis was adopting the space-time domains of the natural resources impacts on regional tourism competitiveness.

4- Jason L., May-chiunlo, abang A.M., Chee-ltua Chin and T. Ramayah (2017), studied the impacts of tourism in terms social-cultural, economic, and Environmental and how these reflect on community's perspectives.

According to the issue of the publication by the global stainable tourism council: (GSTC,2017), it proposed four main drivers these are how sustainability be planned and managed, optimize the benefits for local community and lower the negative impacts on the outcomes.

Our current study focused on the application of these four aspects to some tourism companies in the province of Nineveh-Iraq. As far as researchers know, this is the first study in the Middle East to apply these criteria issued by (UN.W.T.O.).

\section{Literature Review}

\subsection{Sustainable Tourism}

It is not clear how we can define the sustainable tourism precisely due the progress and the growth including its integrity with culture and social diversity (Middleton, Hawkins, 1998.Tanja et.al, 2012. 
p.223). But the world tourism organization (UN.W.T.O.) defines sustainable tourism as: "Sustainable tourism development meets the needs of present tourists and host regions will be protecting and enhancing opportunities for the future. It is envisaged as leading to management of all resources in such a way that economic, social and aesthetic needs can be fulfilled while maintaining cultural integrity, essential ecological processes, biological diversity, and life support system".

\subsection{Dimensions of sustainable tourism}

To increase the sustainable tourism on should know that the environmental impacts could have negative compared to the outcomes of economic and whereas the social impact might have mixtures of results as shown in Figure 10 (W.T.O. and martin M. and fanmunt, 1998).

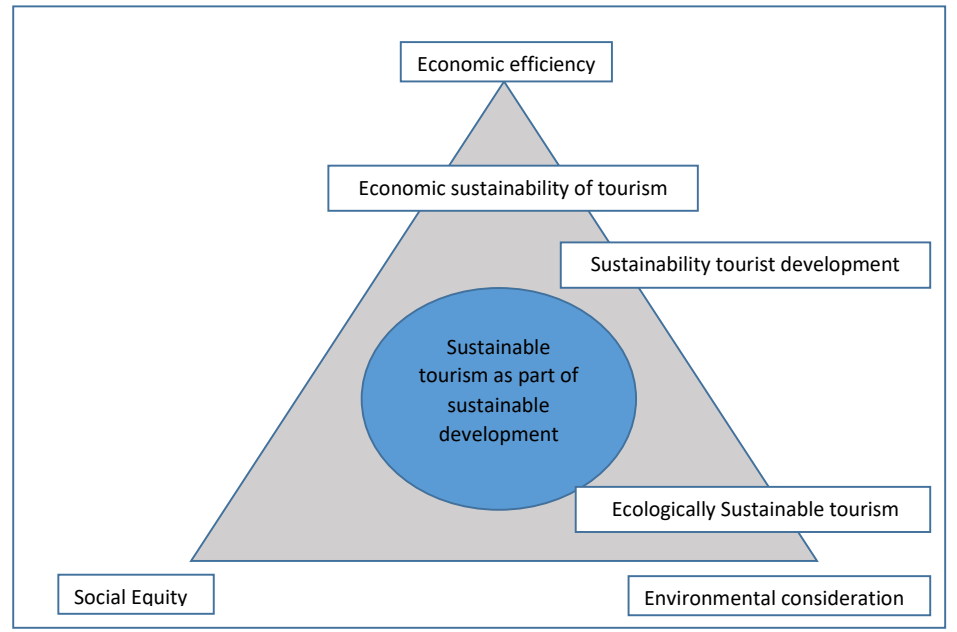

Figure (1). Sustainable Tourism \& Development: https://tourismnotes.com/sustanable-tourism

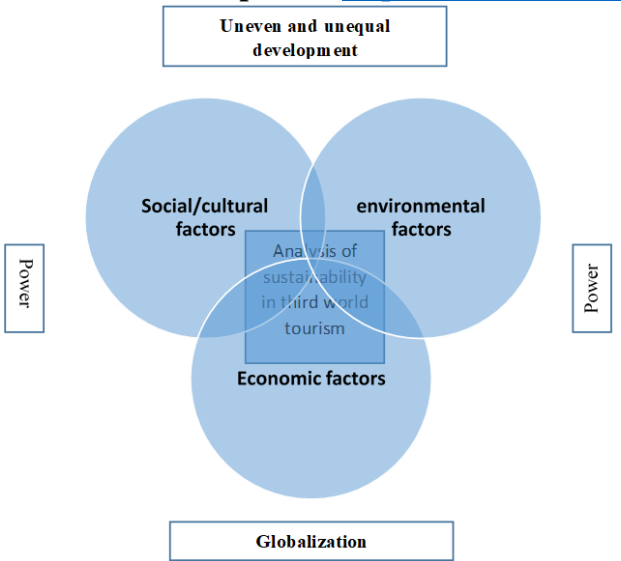

Figure (2); Three Dimensions of Sustainable Tourism: Source: Martin and Munt (1998:37) 


\section{The following are the three dimensions of sustainable tourism; these are:}

\section{1- Environmental Dimensions}

It is very important to have sustainable environment based on the original findings of natural landscape (Seleni matus,2012;11); such as, natural Resources, Natural Environment, farmed environment, including the wildlife and how the build the Environment.

\section{2- $\quad$ Economic Dimensions}

It is very important factor in driving the economy of the industry and improve the financial managements. The benefits and cost of tourism are the main economic dimensions.

\section{3- Social dimension}

It is approved that the social outcomes can support the pathways towards sustainable tourism through the correlated this through the society and culture that has direct influence on the economic and social development in reducing the costs.

\section{3 tourism competitive advantage}

Reasonable review to appoint the tourism ideology into unique purpose (Capraresuc, Daniela and Stancu, 2013), based on wide area of planning from the government and along the pathway of the stakeholders (Oye, Okafor,and Kinjir 2013); besides, the market development sector (Gorman 2005), (Richie and crouch 1993).

\section{Methodology:}

\subsection{Instrument}

After an in-depth review of related literature, a questionnaire with (35) statement was used in this study for gathering primary data. It consists of (3) sections, the first covered demographical characteristics. The second consists of twenty-eight (28) statements that were designed to measure the four dimensions of sustainable tourism development (STD) (independent variables), and the third section implies seven (7) statements focusing on the variables related to achieving competitive advantages in the tourism sector (dependent variables).

Population and sample: The target population was employees of hotels, travel agencies, restaurants and education institutions in the Nineveh Government - North of Iraq). The convenient sampling technique used in this study is extremely speedy, easy, and cost-effective, causing it to be an attractive option for most researchers (Henry 1990). Thus, two hundred forty (240) were collected for 35 questionnaire items represented by five-point scale. Two hundred twenty (220) questionnaires were received, however, two hundred six (206) were valid and ready for analysis from the targeted participants as shown in table (1) below.

Table (1) Questionnaire response rate

\begin{tabular}{|l|l|l|l|l|}
\hline companies & Distributed & Received & Valid & Response rate \\
\hline hotels & 52 & 50 & 48 & $96 \%$ \\
\hline restaurants & 50 & 45 & 42 & $90 \%$ \\
\hline Travel agencies & 48 & 43 & 40 & $89.5 \%$ \\
\hline souvenirs shops & 40 & 36 & 36 & $90 \%$ \\
\hline
\end{tabular}




\begin{tabular}{|l|l|l|l|l|}
\hline Educational institutions & 50 & 44 & 40 & $88 \%$ \\
\hline Total & $\mathbf{2 4 0}$ & $\mathbf{2 2 0}$ & $\mathbf{2 0 6}$ & $\mathbf{9 3 \%}$ \\
\hline
\end{tabular}

\subsection{Data Analysis}

\subsubsection{Data Descriptive Analysis}

As shown in table (2) below. The descriptive analysis of data indicates that $75.2 \%$ of respondents are male, $46.6 \%$ of the sample members have a bachelor's degree. in the target sample, different functional and managerial Ares were represented: experience in the field about $44.3 \%$ had between (4-7) years and (36.4\%) more than 7 years, it means they had a good experience. In addition, about $60 \%$ of employees had good training programs (two and three courses) in the tourism and hospitality field. The respondents of the study simply divided into five tours sectors (hotels $\%$, restaurants $\%$, travel agents $\%$, souvenirs shops $\%$ and educational institutions). The sample covering different aspects.

Table (2) Descriptive Analysis -Profile of respondents

\begin{tabular}{|c|c|c|}
\hline $\begin{array}{l}\text { Demographic and functional } \\
\text { variables }\end{array}$ & Frequency & Percentage $\%$ \\
\hline Gender: MalelFemale & $155 \backslash 51$ & $75.2 \backslash 24.8$ \\
\hline $\begin{array}{l}\text { Educational level: Secondary } \\
\text { IDiplomalBAIMaster \&PHD }\end{array}$ & $14 \backslash 58 \backslash 96 \backslash 38$ & $6.8 \backslash 28.2 \backslash 46.6 \backslash 18.4$ \\
\hline $\begin{array}{l}\text { Experience in field: } 1-3 \text { yearl4-7 } \\
\text { yearslMore than } 7 \text { years }\end{array}$ & $46 \backslash 85 \backslash 75$ & $22.3 \backslash 41.3 \backslash 36.4$ \\
\hline $\begin{array}{l}\text { Training programs: One courses } \\
\text { Two courses } \backslash \text { Three courses } \backslash \text { More } \\
\text { than three courses }\end{array}$ & $48 \backslash 84 \backslash 36 \backslash 48$ & $23.3 \backslash 40.8 \backslash 17.5 \backslash 18.4$ \\
\hline $\begin{array}{lr}\text { Specialization: } & \text { Hotels } \backslash \\
\text { Restaurants\Travel } & \text { agents } \backslash \\
\text { Souvenirs shops } \backslash \text { Educations }\end{array}$ & $57 \backslash 40 \backslash 49 \backslash 47 \backslash 29$ & $27.7 \backslash 19.4 \backslash 23.8 \backslash 22.8 \backslash 14.1$ \\
\hline Total & 206 & $100 \%$ \\
\hline
\end{tabular}

\subsubsection{Sustainable Tourism Development}

With regard to grand means and standard deviations ranged from 3.99 to 4.07 in which the grand mean reached (4.03), which greater the valued (3) that represents the five-point Likert-type scale used in this study tool. The table (3) below indicates that respondents expressed their evaluation with the implementations related to the dimension sustainable tourism which were ordered as the following values of the grand mean (sustainable management, 4.01, social \& economic benefits to local communities 4.07, advantages arising from cultural heritage 4.5, and green environment 3.99). In addition, the grand mean of competitive advantage reached (4.02).

Table (3) Grand mean and standard division

\begin{tabular}{|l|l|l|l|}
\hline Dimensions & Mean & SD. & Importance \\
\hline Sustainable management & 4.01 & 0.63 & 3 \\
\hline Social \& economic benefits to local communities & 4.07 & 0.48 & 1 \\
\hline Advantages arising from cultural heritage & 4.05 & 0.54 & 2 \\
\hline Green environment & 3.99 & 0.78 & 4 \\
\hline
\end{tabular}




\begin{tabular}{|l|l|l|l|}
\hline Grand mean (STD) & 4.03 & & \\
\hline Grand mean (CA) & 4.02 & & \\
\hline
\end{tabular}

\section{7-3. Examining Reliability and Collinearity Diagnostics of Scale Items}

Cronbach's alpha was used in this study based on applied instrument (Spiliotopoulou, 2009) with regard to Cronbach's alpha values ranged from (0.694-0.892) as illustrated in the Table (4) below. Also, the total values of both: sustainable tourism and competitive advantages reflect a good degree of internal consistency taking into account that both exceed the valid value limit of (0.60) (Cronbach and shavelson 2004), this is confirmed by calculated values of sustainable tourism and competitive advantages with (0.820) and 0.812$)$ respectively.

Table (4) Reliability and collinearity Test

\begin{tabular}{|l|l|l|l|l|}
\hline Variables & Reliability test & Reliability test & Collinearity test & VIF \\
\hline & $\begin{array}{l}\text { No. of } \\
\text { statements }\end{array}$ & $\begin{array}{l}\text { Cronbach's } \\
\text { alpha }\end{array}$ & Tolerance & \\
\hline Sustainable management & 10 & 0.823 & 0.702 & 1.424 \\
\hline Benefits to local community & 7 & 0.694 & 0.682 & 1.467 \\
\hline Advantages created by heritage & 5 & 0.769 & 0.531 & 1.882 \\
\hline Green Environment & 6 & 0.892 & 0.514 & 1.944 \\
\hline STD (28 statement) & - & 0.820 & - & - \\
\hline CA (7 statement) & - & 0.812 & - & - \\
\hline $\begin{array}{l}\text { KMO (0.887) } \\
\text { (Sig. 000) }\end{array}$ & - & - & - & - \\
\hline
\end{tabular}

In addition, table (4) illustrates the results of the collinearity diagnostics test. In the presence of collinearity, regression estimates are unstable and have high standard errors (Dormann et al., 2013). Thus the collinearity analysis results indicate that the consistent patterns of relationships among the variables (VIF $<10$ for all sustainable tourism dimensions) are reliable. The test (KMO) and battles show that statements are suitable for performing the analysis, which is confirmed by the (KMO) value of (0.887) are more than (0.7) and the tests significant value (0.000) is less than (0.5).

\subsection{Hypothesis Test}

Main Hypothesis: H01: There is no statistical impact of sustainable management development (SMD) on competitive advantages (CA). As shown in the Table (5) R-value is (0.662) which indicates the correlation between independent and the dependent variables. Also, F-value (33.606) which is significant at (0.05) level confirm that there is a statically significant effect of sustainable tourism development (STD) dimensions on competitive advantages (CA). This result has obligated us to reject the null hypothesis and accept the

Table (5) Test of the main hypothesis

\begin{tabular}{|l|l|l|l|l|l|l|}
\hline Model & $\mathbf{R}$ & $\mathbf{R 2}$ & $\begin{array}{l}\text { F- } \\
\text { Calculation }\end{array}$ & Sig. & DF & F-tabulation \\
\hline 1 & 0.662 & 0.339 & 33.606 & 0.000 & 201 & 3.84 \\
\hline
\end{tabular}


The alternative hypothesis, which states: There is a SS outcomes at $\alpha \leq 0.5$ of sustainable tourism on competitive advantage. The R-squared (R2) explains the linear relationship between the observed and predicted values. Thus, the value of (R2) shows that (34\%) of the variance of the outcome variable (competitive advantage) is explained by the model (sustainable tourism dimensions).

Sub-Hypothesis Test: H01.1. There is no strong probabilistic significant impact at SL $\alpha \leq 0.05$ for the sustainable management dimension on the competitive advantage that some results detailed in Table (6).

Table (6) Test of Sub-Hypothesis H0.1.1 (Sustainable management) (*)

\begin{tabular}{|l|l|l|l|l|l|}
\hline Independent variables & Coefficients B & STD error & T- value & Sig. \\
\hline Constant (BO) & 2.733 & 0.209 & 13.578 & 0.000 \\
\hline Sustainable management & 0.287 & 0.050 & 5.797 & 0.000 \\
\hline Correlation coefficient (R) & \multicolumn{2}{l|}{ Determination coefficient (R2)=0.137 } & \\
\hline F-value $=33.606$ & Sig. of $(\mathrm{F})=0.000$ &
\end{tabular}

(*) $(\mathrm{T}$-tabulation $=1.96),(\alpha \leq 0.05),(\mathrm{F}$-tabulation $=3.84, \alpha \leq 0.05)$

According to the coefficient Table (6) the results indicate to the following: a) The validity of the linear regression model is proven, this confirms by the calculated value of $(\mathrm{F}=33.606)$ which is greater than F-tabulation (3.84) and the SS of (F) equal to 0.0 is less SL $\alpha=0.05$. b) the value of determination coefficient $(\mathrm{R} 2=0.137)$ indicates that the change in sustainable management, explain (13.7\%) percentage of the changes that occur. In the competitive advantage. c) Make sure to prove of the statistical significance of the regression coefficient (B) of sustainable management. This is supported by the calculated $\mathrm{t}$-value $=(5.797)$ which is greater than the $\mathrm{t}$-tabulation $(1.96)$ and the (sig.) for this dimension is less than the significance level $(\alpha=0.5)$ Thus the null-hypothesis (H01.1) was rejected and the alternative hypothesis (H01.1a) was accepted.

$\mathrm{H} 01.2$. There is no strongly dependent impact at SL $\alpha \leq 0.05$ for the social and economic benefits to local communities (BLC) on the competitive advantages. According to the coefficient table (7) the results indicate: the calculated value of $(\mathrm{F})=(57.558)$ that is bigger than 3.84 , and the statistical significance of $(F)=(0.0)$ is less than the SL $\alpha \leq 0.05$. Besides, this explains $(21.6 \%)$ of the changes that occur in competitive advantages. Table (7) shows the (t-value) $=7.587$ which is greater than the $\mathrm{t}$-tabulation $=1.96$, and the statistical significance (sig.) for this dimension is less than the SL $\alpha \leq$ 0.05 .

Table (7) Test of (H01.2) social and economic benefits to local community

\begin{tabular}{|l|l|l|l|l|}
\hline Independent variable & Coefficients $B$ & Standard error & t-value & Sig. \\
\hline Constant $B 0$ and economic & 0.519 & 0.280 & 6.840 & 0.000 \\
\hline $\begin{array}{l}\text { Social local } \\
\text { benefits to } \\
\text { community }\end{array}$ & 0.068 & $7.587(*)$ & 0.000 \\
\hline $\begin{array}{l}\text { Correlation coefficient } \\
(\mathrm{R})=0.465\end{array}$ & Determination coefficient (R2) $=0.216$ & \\
\hline F-value=57.558 & Sig. of $(\mathrm{F})=0.000$ & \\
\hline
\end{tabular}

(*) $($ T-tabulation=1.96), and $(\mathrm{F}$-tabulation $=3.84),(\alpha \leq 0.05)$ 
Thus the null hypothesis (H01.2) was rejected, and the alternative hypothesis (H01.2a) was accepted which states: there are statically significant social and economic benefits to the local community on competitive advantages in H01.3. There is no important outcomes at the SL $\alpha \leq 0.05$ for the advantages arising from cultural heritage $(\mathrm{ACH})$ on competitive advantages. The table (8) shows the test of (hypothesis H01.3); the value of $(\mathrm{F})$ calculated $=(124.754)$, which is greater than Ftabulation (3.84) and the statistical significance of (F) equals to (0.000) is less than the significance level $(\alpha=0.05)$. This indicates that the change in the cultural and heritage dimension explains (37.4) the percentage of the changes that occur in the competitive advantages.

Table (8) Test of (H0.1.3) Advantages of cultural heritage

\begin{tabular}{|c|c|c|c|c|}
\hline Independent variable & $\begin{array}{l}\text { Coefficient } \\
B\end{array}$ & Standard error & t-value & Sig. \\
\hline Constant $\beta$ & 1.611 & 0.218 & 7.396 & 0.000 \\
\hline Cultural and Heritage & 0.595 & 0.053 & $11.169(*)$ & 0.000 \\
\hline $\begin{array}{l}\text { Correlation coefficient } \\
(\mathrm{R}=0.611)\end{array}$ & \multicolumn{4}{|c|}{ Determination coefficient $(\mathrm{R} 2)=0.374$} \\
\hline F-value $=124.754$ & \multicolumn{4}{|c|}{ Sig. of $F=0.000$} \\
\hline
\end{tabular}

At the same time, the t-value $=(11.169)$, which is greater than the t-tabulation (1.96), and the statistical significance (sig.) for these dimensions the SL less than $\alpha=0.05$. Thus H0.1.3 was rejected, and the alternative hypothesis (H01.3a) was accepted which states: there are important probabilistic impacts at SL $\alpha \leq 0.05$ for which cultural and heritage dimensions on the competitive advantages. H01.4. There is no statistically significant impact at the SL $\alpha \leq 0.05$ of preserving and protecting the tourism green environment (GE) on competitive advantages. The value of (F) calculated $=(3.654)$ which is less than F- tabulation (3.84) and the statistical significance (sig.) of (F) equals to 0.66 is greater than the SL $\alpha \leq 0.05$. Besides, the value of the determination coefficient $(\mathrm{R} 2=0.048)$, indicates that the change in the tourism green environmental dimension, explains $(4.8 \%)$ the percentage of the changes that occur in the competitive advantages. Not proven the statistical significance of the regression coefficient (B) of the green environment dimension. This is supported by the calculated (t-value $=1.378$ ), for which $\alpha \leq 0.05$ based on H01.4 that was accepted for the tourism green environment dimension on the competitive advantages $B$.

Table (9) Test of (H1.4) Tourism Green Environment (*)

\begin{tabular}{|l|l|l|l|l|}
\hline Independent variable & Coefficient B & Standard error & t-value & Sig. \\
\hline Constant (B O) & 2.22 & 0.215 & 10.358 & 0.000 \\
\hline $\begin{array}{l}\text { Preserving and protecting } \\
\text { the tourism green } \\
\text { environment }\end{array}$ & 0.175 & 0.127 & $1.378\left({ }^{*}\right)$ & 0.048 \\
\hline $\begin{array}{l}\text { Correlation coefficient } \\
(\mathrm{R})=0.214\end{array}$ & \multicolumn{5}{|l}{} & \\
\hline F-value=3.654 & Sig. of (F)=0.69 & \\
\hline
\end{tabular}

$(*)($ T-tabulation $=1.96)$ and $(\mathrm{F}$-tabulation $=3.84)(\alpha \leq 0.05)$. 


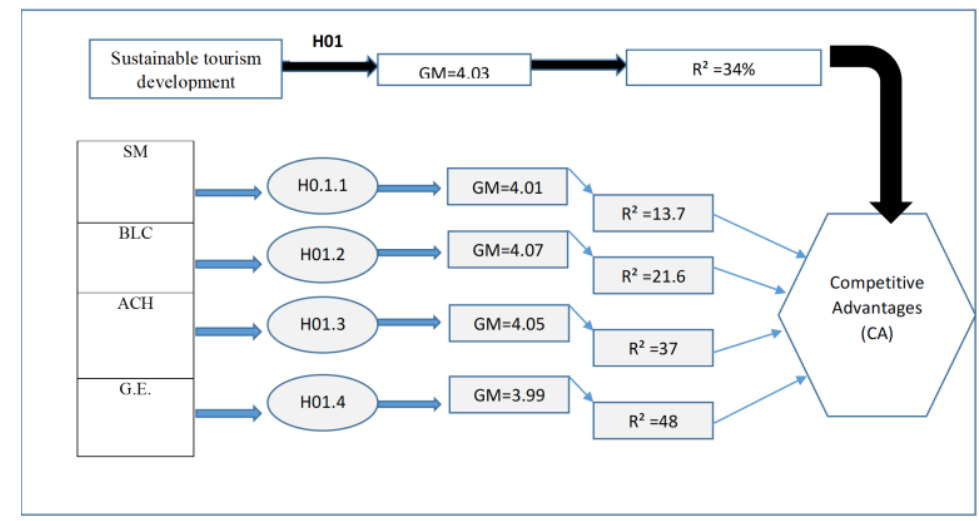

Figure (5) Results of Model Test.

\section{Findings and Discussion}

It is confirmed that there is association between sustainable tourism dimensions and competitive advantages as shown in figure (5), which concludes the results emerged of data analysis. Based on the statistical analysis results, a significant effect was found as a result of applied sustainable tourism practices on the competitive advantages in the Nineveh Government /north of Iraq, which indicates the interaction and coherence between those both dimensions, from communities' perspectives. This result is in agreement with the study of (seleni matus, 2012) that demonstrated a positive effect of sustainable tourism development. At the same orientation the study by (Tanja A., Cane K., Zlatko J.\& Elizabeta M. (2012) has confirmed that largely influenced by the quality of the environment to preserve and attractive natural and cultural heritage and other values, goods and resources. This study agrees with the perception of Romanian toward the tourist destination (Mazilu mirela, 2015); however the study by, João Romāo, G. Guerreiro and Paulo Rodringues (2017), stated that natural resources has no strong impact on mass tourism whereas Jason et.al (2017), correlated the sociocultural rural tourism.

The results of our study indicated the clear role of sustainable management (SMD), benefits of social and economic to local communities (BLC), advantages from cultural heritage (ACH) in the achievement of competitive advantage, while the results were confirmed the lack of green environment impact on competitive advantages. Also, the study suggests many recommendations as following;

- The commitment of companies operating in the tourism and hotel services sector with instructions and regulations related to environmental protection.

- Careful of the departments of these companies on the economy, conversation and optimal use of sources or inputs of production in general.

- Supporting any creative ideas that promote environmental conversation through environmental activities and programs.

- Supporting and encouraging research and studies related to green tourism marketing.

- Organizing workshops and workshops on awareness of the importance of preserving tourist destinations and places.

- The community provision improves the green tourist environment. 


\section{References}

[1] Capraresuc, G., Daniela, L., and Stancu, G., Quality by keeping the identify or how to obtain competitiv92005e advantage in Romanian rural tourism. International journal of academic research in economics and management sciences 2(1), 1-5. (2013).

[2] Clark, Heather Muslim Militants blow up tombs of biblical Jonah, Daniel in Iraq, http://christiannews. (2014)

[3] Cronbachl. And Shoulson R my current thoughts on confident alpha and success procedures. Educational and Psychological Measuerment.64 (3) pp.391-418. (2004)

[4] Dana, L.P. Economies of Eastern Mediterranean Region: Economic miracles in the making, Singapore, London and Hong Kong: World scientific. (2000)

[5] Dormann,C.F,Elith,J.,Bacher,S.,Buchmann,C., and carl ,G. et AL Collinearity: A review of methods to deal with it and A "Simulation study evaluating their performance.Ecography,36(1)pp.27-46. ., (2013)

[6] Eagles, P.F.J., Mecool, S.F., and hynes, C. F. Sustainable tourism in protected area: guidelines for planning and management.gland.switizerlan: international union for the conservation of nature. (2002)

[7]Global sustainable tourism criteria (https://shapingsustainablemarkets.iied.org)

[8] Global sustainable tourism councel: global sustainable tourism criteria for tourism industry (GSTCindustry) version1.1.December 2015.

[9] Gorman, C. co-operative marketing structures in rural tourism: the irish case in D. hall, I. 10Kirkpatrick and M. Mitchell (Eds.) rural tourism and sustainable business (pp.121-137) Dublin: channel view publication. (2005)

[10] Henry, G.TPractical sampling, Newbury Park: sage publication. http://tourismnotes.com/sustainabletourism/. (1990)

[11] Jason Lim, May-Chiun Lo, Abang A., Chee-Hua Chin, T. Ramayah.The moderating impact of community support on tri-dimensional impacts of tourism (Economic, Socio-cultural, and environmental) towards rural tourism competitive advantages, Journal of business and society, vol.1854, 2017, pp.869-880. . (2017)

[12] Jukowsky, Institute for archeology and the ancient world.brown University. , (2011)

[13] Joao Romao, J. Guerreiro and Paulo Rodrigues.Territory and Sustainable tourism development: a spacetime. Analysis on European regions.vol.4, no.3 (2017), Region. http://doi.org/10.18335/region.v4i3.142.

[14] K.R. Veenhof Mesopotamia: The old Assyrian period, Vanden hoeck and Ruprechl, p.24 (2008).

[15] Lioyed, Anthony Inside the Assyrian place revealed in fight for Mosul, http://www.thetimes.co.uk/edition. (2017).

[16]Martin Mowforth and Ian Mant .Tourism and sustainability, new tourism in the third world. Routledge publisher, London, USA and Canada. (1998).

[17] Mazilu mirela .The perception of Romania as a tourist destination into sustainable development WVLFENA, No.6, Vol.22, jun2015. (2015).

[18] Middleton, V.T.C, Hawkins, R. sustainable tourism -A market perspective, Butterworth-Heirman, oxford. (1998)

[19] Oye, N.D., Okafor, C.I., and kinjir, S. sustaining tourism destination competitiveness using ICT. In developing counties. International journal of computer and information technology, 2(1), 48-56. (2013)

[20] Richie, B.J.R. and Cruch, G.I.60 competitiveness in international tourism-A framework for understanding and analysis. Reports on $43^{\text {rd }}$ congress, 35, pp. 23-71. . (1993)

[21] Seleni matus Sustainable as a source of competitive advantages in the travel and tourism industry destination management, October, 11.2012. (2012)

[22] Sebele, L. S. Community-based tourism ventures, benefits and challenges: Khama rhino sanctuary trust, central district, Botswana.tourism management, 31,136-146. (2010).

[23] Sieglinde kinl de cunba and Joao cunba Tourism cluster competitiveness and sustainability: proposal for a systematic model to mesure the impact of tourism on local development. BAR-Brazilian administration review, vol.2, july-december 2005, pp.47-62. 
[24] Spilioto pouloug. Reliability Reconsidered: Cronbach's alpha and podiatric Assessment in occupational therapy, Austalian occupational therapy journal, 56(3) pp. 150-155. (2009)

[25] Tanja A. Cane K., Zlatko J., and Elizabeta M., Sustainability and competitiveness of tourism, procediasocial and behavioral sciences.44 (2012), pp.221-227. http://doi:10.1016/j.sbspro.2012.05.023.

[26] Taylor, G. The community approach: does it really work? Tourism management, 16(7), 487-489. (1995).

[27]United Nation world Tourism organization (UNWTO), Tourism highlights 2019, edition, Madrid, Spain, 2019.

[28] www.sustanabletoutismcreteria.org.GSTCpartnership 